\title{
ABOUT THE SIMILARITIES AND DIFFERENCES BETWEEN SHARED VALUE AND CORPORATE SOCIAL RESPONSIBILITY
}

\author{
R. Angelova* \\ „Industrial Business And Entrepreneurship” Department, Faculty Of Economics, \\ Trakia University, Stara Zagora, Bulgaria,
}

\begin{abstract}
Over the last few years, we have witnessed the rapid development of Michael Porter and Mark Kramer's "Creating Shared Value - CSV" strategy. It builds on the philosophy of Corporate Social Responsibility - CSR and represents a step forward in uniting business and state efforts to address social issues. The author proves this by comparing CSV and CSR and outlining some of their similarities and differences. Clarifying the essence of CSV and highlighting it from CSR are consider to force the impact of this new philosophy in the world of modern business.
\end{abstract}

Key words: shared value, social responsibility, state regulations

JEL: L260; M140

Over the past decade, economic literature has gained popularity the theories of increasing competitiveness and focusing on the relationship between business and society. One of these is Michael Porter's Creating Shared Value (CSV) and Mark Cremer's Creating Shared Value (CSV) concept. In harmony with European priorities, they perfectly combines the focus on sustainability, innovation and growth with responsibility for environmental protection and commitment to social problems and are in harmony with European priorities.

The idea of the relationship between business and society can be found in Adam Smith's theory of "the invisible hand" (9), in which the notion that "personal interests produce the public good" (1). A further development of this theory is the philosophy of Corporate Social Responsibility (CSR) that has become popular in recent decades. One of the most well-known definitions of "corporate social responsibility" is that of the International Business Business Forum. Which identifies it as "promoting the practices of responsible business that benefit

\footnotetext{
*Correspondence to: RUMYANA ANGELOVA, „INDUSTRIAL BUSINESS AND

ENTREPRENEURSHIP” DEPARTMENT, TRAKIA UNIVERSITY, FACULTY OF ECONOMICS, STARA ZAGORA, STUDENT CAMPUS BULGARIA, e-mail:rumi2002@abv.bg
}

business and society and promote social, economic and environmental sustainable development by maximizing the positive impact of business on society and minimizing the negative." CSR is reflected in a number of European Union documents, including the European Sustainability Strategy (2001), the International Standard ISO 26000 - Social Responsibility (2010) and a number of national strategies.

In 2006, M. Porter and M. Kramer first used the concept of "shared value" (5). Several years later, they are releasing a new publication in which they express the affirmation that the implementation of CSR has not achieved the expected results. According to them, "the more corporate becomes the business, the more he is accused of social failures "(6). Out of this problem, the authors see the creation of shared value "that is not social responsibility, philanthropy or even sustainability, but a new way to achieve economic success" (ibid.). With this statement, Porter and Kramer place a sign of inequality between CSR and CSV. Business attention is focused on the new concept - Creating Shared Value (CSV). It submits its philosophy of corporate social responsibility ideas and is a step forward in the efforts of the economic community to boost competitiveness. 
CSV is a new ideology that is manifested through many policies and practices aimed at creating value for both the company and society, taking into account its needs and priorities. There are three ways to create a "shared value" (7):

Rethinking products and markets - the focus is on achieving social impact by increasing revenue, market share and profitability by creating new or refining existing products to achieve a social impact. For example, the company BD ("Becton \& Dickinson") in New Jersey, for example, manufacturing medical equipment and apparatus, invented a "needless system" that uses the traditional use of medical syringes with needles. The result of the innovation for the company is a multiplicity of sales growth, and for society a new, painless way of medical intervention and limiting the spread of HIV infections.

Redefining productivity in the value chain - focusing on innovation that will lead to quality and productivity gains, resource savings, etc.

Possibilities for cluster development at local level - the goal is to improve the external environment in which the company operates, based on local infrastructure investments, supporting local suppliers, creating jobs, and so on.

The similarities and differences between the two concepts - Shared Value (CSV) and Corporate Social Responsibility (CSR) are summarized in a Table 1.

Table 1. Similarities and differences between CSR and CSV

\begin{tabular}{|c|c|c|c|}
\hline \multirow[t]{2}{*}{ Indicator } & \multirow[t]{2}{*}{ Similarities } & \multicolumn{2}{|c|}{ Differences } \\
\hline & & CSR & CSV \\
\hline $\begin{array}{l}\text { 1. Social } \\
\text { problems } \\
\text { approach }\end{array}$ & $\begin{array}{l}\text { Business is responsible to } \\
\text { public problems }\end{array}$ & $\begin{array}{l}\text { - The problems of the society } \\
\text { are of the secondary } \\
\text { importance } \\
\text { - The emphasis is on the risk } \\
\text { mitigation in the short term }\end{array}$ & $\begin{array}{l}\text { - The responsibility to society is } \\
\text { society is of a long-term nature } \\
\text { - Social problems are the starting } \\
\text { point for companies' strategies } \\
\text { - The solution of social significant } \\
\text { problems s reflected in joint } \\
\text { participation in projects or programs }\end{array}$ \\
\hline $\begin{array}{l}\text { 2. Business } \\
\text { and society } \\
\text { partnership }\end{array}$ & $\begin{array}{l}\text { A close relationship between } \\
\text { business and society, } \\
\text { represented by the State or } \\
\text { municipal institutions, non- } \\
\text { governmental organizations, } \\
\text { universities and others. }\end{array}$ & $\begin{array}{l}\text { - The partnership is most } \\
\text { often in the form of business } \\
\text { support for solving social } \\
\text { significant problems. }\end{array}$ & $\begin{array}{l}\text { - Formation of clusters, } \\
\text { associations, associations, } \\
\text { foundations and other forms of joint } \\
\text { activity. }\end{array}$ \\
\hline $\begin{array}{l}\text { 3. Creating } \\
\text { value }\end{array}$ & $\begin{array}{l}\text { Harnessing the benefits of } \\
\text { solving social, environment } \\
\text { and economic problems }\end{array}$ & $\begin{array}{l}\text { - The aim is to create a better } \\
\text { reputation } \begin{array}{r}\text { through } \\
\text { participation in charity } \\
\text { initiatives }\end{array}\end{array}$ & $\begin{array}{l}\text { - Creating an economic value based } \\
\text { on creating value for society through } \\
\text { cost-cutting }\end{array}$ \\
\hline $\begin{array}{l}4 . \\
\text { Connection } \\
\text { to the } \\
\text { production } \\
\text { program }\end{array}$ & $\begin{array}{l}\text { Existence of a commitment to } \\
\text { take account of the production } \\
\text { program with the risks it may } \\
\text { cause to society }\end{array}$ & $\begin{array}{l}\text { - Preventive actions to reduce } \\
\text { the risk of environment } \\
\text { pollution. }\end{array}$ & $\begin{array}{l}\text { - The production program is fully } \\
\text { subordinated to the production of } \\
\text { environment-friendly and resource- } \\
\text { efficient products. }\end{array}$ \\
\hline $\begin{array}{l}\text { 5. External } \\
\text { influence }\end{array}$ & $\begin{array}{l}\text { Voluntary, subordination of } \\
\text { the economic policy of the } \\
\text { State. }\end{array}$ & $\begin{array}{l}\text { - According to personal } \\
\text { preferences, programs or } \\
\text { initiatives are implemented, } \\
\text { which are subject to State } \\
\text { regulations }\end{array}$ & $\begin{array}{l}\text { - More necessity and focus on } \\
\text { increasing competitiveness }\end{array}$ \\
\hline $\begin{array}{l}6 . \text { Time } \\
\text { aspect }\end{array}$ & $\begin{array}{l}\text { They do not have an episodic } \\
\text { character }\end{array}$ & $\begin{array}{l}\text { - Part of the company's short- } \\
\text { term strategies }\end{array}$ & $\begin{array}{l}\text { - Part of the company's long-term } \\
\text { strategies }\end{array}$ \\
\hline $\begin{array}{l}\text { 7. Bind to } \\
\text { the company } \\
\text { budget }\end{array}$ & - & $\begin{array}{l}\text { - It is not tied to the company } \\
\text { budget }\end{array}$ & $\begin{array}{l}\text { - The company's budget is fully } \\
\text { compliant with the realization of } \\
\text { shared value concept }\end{array}$ \\
\hline
\end{tabular}

*The table summarizes and comments on the differences between CSR and CSV of the following publications: $(6) ;(4) ;(2)$. 
The similarities and differences that appear in the table show that CSV is a kind of continuation and futher development of CSR ideas. It focusses on implementing business strategies through compliance and integration with society, but in the long run. The pursuit of higher profit is in line with social need. The motivation of managers is not limited to achieving good reputation but also real benefits to society. Their contribution is to invest resources, wich are economically and socially justifiable. Companies hosting CSV, must must necessarily take account of how their activities impact the environment in which they operate and limit their own negative influence.

Great Western companies such as General Electric, IBM, Intel, Johnson \& Johnsonq Nestle and others adopt the CSV concept. They are justified by the argument of its advantage, which consists in "building the concept of perception that in the long run, the interests of business and society can intertwine and complement each other, bringing both profit and dividends for business and benefit for the society whose needs will be satisfied "(3).

\section{REFERENCES}

1. Butler, I., A. Smith, Introduction, Institute for Radical Capitalism. C.: Atlas, Sofia, p. 91., 2010.

2. Crane A., G. Palazzo, L. Spence, D. Matten, Contesting the Value of "Creating
ANGELOVA R.

Shared Value", Vol. 56. Berkeley: University of California, 2014.

3. Dimitrova, C., Shared Value or Shared Values? The presence of shared values determines the ability to create shared value, Shared Values Shared Values. Magazine for Industry, Clusters and Shared Value., March, March, p.50, 2014.

4. Hidalgo, Ch. Are Shared Value and Corporate Social Responsibility Different? A Sustainability Report Re-Imagined. FSG, October, 2014.

5. Porter, M. E., M. R. Kramer, Strategy \& Society. The Link between Competitive Advantage and Corporate Social Responsibility. - Harvard Business Review, December, 2006.

6. Porter, M. E., M. R. Kramer, Creating Shared Value - How to reinvent capitalism - and unleash a wave of innovation and growth. - Harvard Business Review, January - February, 2011.

7. Porter, M., G. Hills, M. Pfitzer, S. Patscheke and E. Hawkins . Measuring Shared Value. How to unlock value by Linking Social and Business Results. FSG, 2011.

8. Porter, M. (2014). Shared Value in Chile Increasing Private Sector Competitiveness by Solving Social Problems. Universidad del Dessarollo, FSG, 2014.

9. Smith, A., Wealth of Nations, Published by "Partizdat", 1983. 